\title{
Persons with Intellectual Disability and Access to Justice in Nigeria: Challenges and the Way Forward
}

\author{
Augustine Edobor Arimoro \\ Faculty of Law, University of Cape Town, South Africa. \\ E-mail:augustine.arimoro1@gmail.com
}

\section{ARTICLE INFO}

Keywords:

Disability; Human Rights;

Intellectual Disability;

Nigeria

How to cite:

Arimoro, A. E. (2019).

"Persons with Intellectual

Disability and Access to

Justice in Nigeria:

Challenges and the Way

Forward," Hasanuddin Law

Review, 5(2): 180-198

DOI:

10.20956/halrev.v5i2.1561

\begin{abstract}
Conservatively, there are approximately about two million persons in Nigeria who may be referred to as persons with intellectual disabilities. These persons suffer from several challenges ranging from economic to non-inclusion in the society. In the paper, the discussion focuses on persons with intellectual disabilities and the effective access to justice as a fundamental right. The paper finds that even though Nigeria has adopted and ratified the United Nations Convention on the Rights of Persons with Disabilities, the Federal Government of Nigeria has not been proactive in supporting the persons with disabilities in the country to enjoy these rights. Furthermore, despite the provision in the 1999 Constitution of the Federal Republic of Nigeria to ensure freedom from discrimination, there is no direct effect on procedure to ensure that the rights of the disabled persons are protected. The paper proposes for a framework for the protection of the person with intellectual disability which includes legal protection, legal awareness, legal aid, adjudication and for civil society oversight of the access of persons with intellectual disabilities to justice.
\end{abstract}

Copyright () 2019 HALREV. All rights reserved.

\section{Introduction}

The well-being of persons with disabilities (PWD) should be of concern to any society. ${ }^{1}$ This is so because about 16 per cent of the world's population is challenged by one form of disability or the other. ${ }^{2}$ As it relates to Nigeria, out of a population of over 187 million

1 Augustine Edobor Arimoro, 'Are They not Nigerians? The Obligation of the State to end Discriminatory Practices against Persons with Disabilities' (2019) 19(2) International Journal of Discrimination and the Law 90.

2 Amy Raub, Isabel Latz, Aleta Sprague, Michael Ashley Stein and Jody Heymann, 'Constitutional Rights of Persons with Disabilities: An Analysis of 193 National Constitutions' (2016) Harvard Human Rights Journal 29 at 203 
persons, ${ }^{3}$ an estimated 25 million persons are living with a disability ${ }^{4}$ representing about 13.37 per cent of the country's population. Considering that a significant number of the world's population in general, and in Nigeria in particular, are affected by this, the need to examine how the rights of such persons are protected becomes imperative.

The United Nations, in recognition of the rights of PWD, championed, in 2006, a charter for the advancement of the rights of such persons through the United Nations Convention on the Rights of Persons with Disabilities (CRPD)..$^{5}$ The Convention and its Optional Protocol 6 was adopted on 13 December 2006 at the United Nations Headquarters in New York, and was opened for signature on 30 March 2007.7 As of August 2018, a total of 177 countries, including Nigeria, have ratified the CRPD. ${ }^{8}$ Article 1 of the CRPD sets its purpose, which is 'to promote, protect and ensure the full and equal enjoyment of all rights and fundamental freedoms by all persons with disabilities, and to promote respect for their inherent dignity.'

Despite Nigeria's ratification of the CRPD and after over a decade of committing to protecting the rights of PWD, how has Nigeria fared in living up to this commitment? This paper examines the rights of PWD (and specifically that of the person with intellectual disability) under international instruments and the 1999 Constitution of the Federal Republic of Nigeria (as amended) with the aim of determining what is obtainable, what has been done and what should be done to advance the rights of such persons. In the light of Article 12 of the CRPD which provides that persons with disabilities are entitled to full legal capacity on equal basis with others and obliges state parties to provide access to support that they may require exercising this legal capacity, this paper focuses on the plight of persons with intellectual disability and the right to have access to justice in Nigeria. In the next section of the paper, I reflect on what disability is.

\section{What is a Disability?}

Nearly everyone living will one day be temporarily or permanently be impaired at some point in their lifetime. ${ }^{9}$ Those who survive to old age could encounter difficulties in going about their daily activities. ${ }^{10}$ It is also true that nearly every family has, or is close to someone who suffers a disability. ${ }^{11}$ The term disability is multidimensional and has

3 Yemisi Adegoke, 'UN: Half of World's Population Growth is Likely to Occur in Africa' CNN 26 June 2017 available at <https://edition.cnn.com/2017/06/25/africa/africa-population-growth-un/index.html> accessed 31 July 2018.

4 Mohammed Awaisu Haruna, 'The Problems of Living with Disability in Nigeria' (2017) Journal of Law, Policy and Globalisation 65 at 103. See also Segun James, 'Over 25m Nigerians are Disabled' Thisday 22 April 2017.

5 Amy Raub, Isabel Latz, Aleta Sprague, Michael Ashley Stein and Jody Heymann, op cit (note 1) at 204.

6 (A/RES/61/106).

7 United Nations, 'Convention on the Rights of Persons with Disabilities (CRPD)' available at $<w w w . u n . o r g / d e v e l o p m e n t / d e s a / d i s a b i l i t i e s / c o n v e n t i o n-o n-t h e-r i g h t s-o f-p e r s o n s-w i t h-d i s a b i l i t i e s . h t m l>$ accessed 1 August 2018.

8 Ibid. Nigeria ratified the UN CRPD on 24th September 2010 and hosted the Africa Regional Community-Based Rehabilitation Conference on 7th October 2010 thereby putting the PWD issues on the agenda of the country for policy making.

9 World Health Organisation, World Report on Disability (World Health Organisation/The World Bank 2011) 3.

10 Ibid.

11 Ibid. 
been conceptualised in various forms including medical, socio-political, economic and in administrative perspectives. There is no universally accepted definition of the term disability as there exists some distinction in definitions that have been proffered. ${ }^{12} \mathrm{It}$ appears that the different definitions are intended to suit various purposes. ${ }^{13}$

A few definitions of the term are provided here. Disability has been defined as 'a condition of function judged to be significantly impaired relative to the usual standard of an individual functioning, including physical impairment, intellectual impairment mental illness, and various types of chronic disease. ${ }^{\prime 14}$ It is important that in defining the term disability, that it should be applicable to all people without a demarcation into groups such as 'wheel chair users' or 'the visually impaired.' ${ }^{15}$ According to the World Health Organisation, disabilities is an umbrella term, covering impairments, activity limitations, and participation restrictions.' ${ }^{16}$ Furthermore, 'an impairment is a problem in body function or structure; an activity limitation is a difficulty encountered by an individual executing a task or action; while a participation restriction is a problem experienced by an individual in involvement in life situations.' 17 Disability is therefore, not just a health problem but a complex phenomenon that touches on the features of a person's body and features of the society where that person lives. ${ }^{18}$

It will not be out of place to consider some statutory definitions of the term. In the United Kingdom, with the exception of Northern Ireland, the term disability is defined as follows:

A person $(\mathrm{P})$ has a 'disability' if:

(a) P has a physical or mental impairment, and

(b) the impairment has a substantial and long-term adverse effect on her or his ability to carry out normal day-to-day activities. ${ }^{19}$

In Nigeria, the law only offers a definition of the term 'disabled person' and not 'disability.' It states as follows:

'Disabled person' means a person who has received preliminary or permanent certificate of disability to have a condition which is expected to continue permanently or for a considerable length of time which can reasonably be expected to limit the person's functional ability substantially, but not limited to seeing, hearing, thinking, ambulating, climbing, descending, lifting, grasping, rising, and any related function or any limitation due to weakness or significantly decreased endurance so that he cannot perform his everyday routine, living and working without significantly increased hardship and vulnerability to everyday obstacles and hazards. ${ }^{20}$

12 Theresia Degener, 'Definition of Disability' (2004) available at <www.pedz.unimannheim.de/daten/edz-ath/gdem/04/disabdef.pdf> accessed 13 September 2018.

13 Lars Grönvik, Definitions of Disability in Social Sciences (Uppsala University 2007) 13.

14 Disabled World, 'Disability: Definition, Types and Models' (2018) available at <www.disabledworld.com/disability/types/> accessed 11 September 2018.

15 Matilde Leonardi, Jerome Bickenbach, Tevfik Bedirhan Ustun, 'The Definition of Disability: What is in a Name?' (2006) The Lancelot 368 (9543) at 1219

16 World Health Organisation, 'Health Topics: Disabilities' (2018) available at < http://www.who.int/topics/disabilities/en/> accessed 13 September 2018.

17 Ibid.

18 Ibid.

19 S. 6(1) of the Equality Act 2010

20 S. 3 Nigerians with Disability Decree 1993. 
It is hard to fathom why the law ${ }^{21}$ in Nigeria requires a certificate to show that a person is disabled. It is worthy of note that the Nigerian law only stops at the obligation of the government to provide public and private funding support for legal clinics for the disabled ${ }^{22}$ without any provision to ensure the disabled get equal access to justice other than the provision of legal services.

For the purposes of this paper, disability is defined as any physical or mental condition that affects a person's ability to move normally or affects the person's senses or limits the person's ability to be active. In the next sub-section of the paper, intellectual disability is introduced and examined.

\subsection{Intellectual Disability: What is it?}

Intellectual disability ${ }^{23}$ affects the way a person who suffers from it learn and it is a challenge that affects people at a time when they are under the age of $18 .{ }^{24}$ Clinically and for the purpose of proving in a court that a person has suffers from that disability, a psychologist must access the person of having an IQ of 70 or less and that the person has deficits in at least two areas of the following adaptive behaviours, namely, communication; self-care; home living; social skills; self-direction; leisure and work; or learning. ${ }^{25}$ It is different from other cognitive disabilities such as mental illness, brain injury, dementia and autism. ${ }^{26}$ Intellectual disability has severe effects on the people who suffer from it as well as the family and community. ${ }^{27}$

According to the American Association of Intellectual and Development Disabilities, 'Intellectual disability is a disability characterised by significant limitations in both intellectual functioning and adaptive behaviour, which covers many everyday social and practical skills. This disability originates before the age of 18.'28 The World Health Organisation defines intellectual disability as follows:

Intellectual disability means a significantly reduced ability to understand new or complex information and to learn and apply new skills (impaired intelligence). This results in a reduced ability to cope independently (impaired social functioning) and begins before adulthood, with a lasting effect on development. 29

21 The 1993 Decree which is not listed in the 2004 Laws of the Federation of Nigeria is the current disability law in the country pending the assent to a new bill on disability.

22 See S. 14 Nigerian with Disability Decree 1993.

23 Sometimes also referred to as mental retardation.

24 Intellectual Disability Rights Service, 'Introduction to Intellectual Disability' (2009) available at < http://www.idrs.org.au/pdf/IDRS_\%20Introduction_intellectual\%20disability_17Feb09.pdf> accessed 13 September 2018.

25 Ibid.

26 Ibid.

27 Abha Shree and PC Shukla, 'Intellectual Disability: Definition, Classification, Causes and Characteristics' (2016) Learning Community 7(1) at 9

28 American Association of Intellectual and Development Disabilities, 'Definition of Intellectual Disability' (2018) available at < http://aaidd.org/intellectual-disability/definition> accessed 13 September 2018.

29 World Health Organisation Regional Office for Europe, 'Definition: Intellectual Disability' (2018) available at <http://www.euro.who.int/en/health-topics/noncommunicable-diseases/mentalhealth/news/news/2010/15/childrens-right-to-family-life/definition-intellectual-disability > accessed 13 September 2018. 
People who suffer from intellectual disability have existed across human history and can be found in all countries of the world. ${ }^{30}$ Persons with intellectual disabilities may be classified as having mild, moderate, severe or profound intellectual disability. ${ }^{31}$ It is estimated that 1 per cent of the world's population suffers from intellectual disability. ${ }^{32}$ Going by that conservative estimate, I assume that out of Nigeria's population of about 198 million persons, ${ }^{33}$ about 1.9 million Nigerians suffer from intellectual disability. The plight of these persons in Nigeria should be of concern especially when it has to do with access to justice where they are either victims, witnesses or accused or pursuing a right in the courts in the country. For the purpose of this paper, intellectual disability is the incomplete mental and cognitive development of a person before the age of 18 . In the context of this paper, reference is to persons with that condition living in Nigeria.

The focus of the paper is to what extent people with intellectual disability living in Nigeria enjoy legal capacity on equal basis with others and what reasonable accommodations are ensured for such persons to access justice. Having identified what intellectual disability is, in the next subsection, the causes of the disability are discussed.

\subsection{Causes of Intellectual Disabilities}

Before dealing with the rights of persons with intellectual disabilities, it may suffice to examine the causes of the condition. The intention here is not to provide an elaborate scientific explanation but rather a cursory glance to provide a basis for the discussion. Intellectual disability may be caused by any condition that results in the impairment of the development of the brain before birth, during birth or in early childhood. ${ }^{34}$

Intellectual disability may be broadly be caused by either environment, genetic or metabolic reasons. ${ }^{35}$ These factors can further be grouped into prenatal, perinatal and postnatal. ${ }^{36}$ It is estimated that about 70 per cent of persons with intellectual disabilities and 50 per cent of those with mild intellectual disabilities have an organic or biological basis for their disorder. ${ }^{37}$ The possible cause may be from the following: ${ }^{38}$

a. Chromosomal abnormality for example down syndrome;

b. Metabolic disorders like phenylketonuria;

c. Maternal infections for example German measles;

d. Environmental conditions like fetal alcohol syndrome;

e. Gestational disorders;

f. Neonatal complications;

30 Trevor R Parmenter, 'What is Intellectual Disability? How is it Assessed and Classified?' (2011) International Journal of Disability, Development and Education 58(3) 303.

31 Abha Shree and PC Shukla, op cit (note 26) 13-14.

32 Pallab K Maulik, Maya N Mascarenhas, Colin D Mathers, Turan Daua and Shekhar Saxena, 'Prevalence of Intellectual Disability: A Meta-analysis of Population-Based Studies' (2011) Research in Development Disabilities 32 at 420.

33 Ifeoluwa Adeyemo, 'Nigeria's Population now 198 million - NPC' Premium Times 12 April 2018 available at < www.premiumtimesng.com/news/top-news/264781-nigerias-population-now-198-millionnpc.html> accessed 13 September 2018.

34 The Arc, 'Causes and Prevention of Intellectual Disabilities' (2011) available at < www.thearc.org/document.doc?id=3667> accessed 13 September 2018.

35 Visnja Tomac, Silvija Puśeljic, Ivana škrlec, Mirna Andelic and Martina Kos, 'Etiology and the Genetic basis of Intellectual Disability in the Paediatric Population' (2017) South Eastern European Medical Journal 1 at 145 .

36 Ibid.

37 Abha Shree and PC Shukla, op cit (note 26) 12.

38 Ibid 13. 
g. Infections; and

h. Environmental factors such as malnutrition, neglect or child abuse.

\subsection{Traits of Persons with Intellectual Disabilities}

Intellectual disabilities may affect the way a person learns, that person may also may be challenges in terms of the ability to adapt to home, school and the environment. This is explained below.

A child with intellectual disability, for instance, may have difficulty in learning and applying skills. In addition, the child may have a higher level of distractibility, inattentiveness as well as the failure to read social clues. ${ }^{39}$ Persons with intellectual disability may have difficulty distinguishing and attending to relevant questions in learning and social conditions. They have delayed speech as well as language comprehension and formulation difficulties. They may also suffer from differing biological aetiologies that affect their motor, orthopaedic, visual state of health. ${ }^{40}$ In the next section of the paper, the society and the person challenged with intellectual disability forms the core of the discussion.

\section{The Society and Persons with Intellectual Disabilities}

Having examined the traits of persons having intellectual disabilities above, it becomes pertinent to review how such persons fair in the family and the larger society. The case of middle to low income countries is interesting as the chances of early detection of the disorder is rare to non-existent. ${ }^{41}$ Persons with intellectual disability are the most vulnerable even among the disabled. ${ }^{42}$ They are usually find communication and relating with other persons difficult which affects their quality of life as well as their physical and mental well-being. ${ }^{43}$ For those with severe disability, their scope for selfadvocacy may only be limited by simple choices such as what to eat, watching TV or the support person they prefer. ${ }^{44}$

Even in developed societies, persons with intellectual disabilities face major stigma, prejudice and constant confrontation with significant barriers to the realisation of their fundamental rights as human beings. ${ }^{45}$ For example, in a contribution on the Irish Examiner, the writer posits that many Irish citizens with intellectual disabilities are not afforded the rights and protection promised them in the constitution. ${ }^{46}$ They are the most marginalised and excluded group in the society. The discrimination against such persons stems from institutional structures and societal prejudice.

39 Ibid 16.

$40 \quad$ Ibid 17.

41 Eduardo Lazcano-Ponce, Guillermna Rangel-Eudave and Gregorio Katz, 'Intellectual Disability and its Effects on Society' (2008) Salud pública Méx 50(2).

42 Inclusion Europe, 'Inclusion of People with Severe and profound Intellectual Disability' (2000) available at <http://www.platformemg.nl/wp-content/uploads/2012/08/inclusionofpeople.pdf> accessed 14 September 2018.

43 Ibid.

44 Ibid.

45 Open Society Institute, 'Rights of People with Intellectual Disabilities: Access to Education and Employment Romania' (2005) available at: <www.opensocietyfoundations.org/sites/default/files/ romaniareport_20050902.pdf> accessed 14 September 2018.

46 Finta Sheerin, 'We Must Change Approach to Intellectual Disability' Irish Examiner 11 September 2009 available at <www.irishexaminer.com/viewpoints/yourview/we-must-change-approach-to-intellectualdisability-100622.html> accessed 14 September 2018. 
In the United Kingdom, for instance a study in 2014 revealed that 67 per cent of the British public feel uncomfortable talking to a disabled person, while 36 per cent think disabled persons are not as productive as everyone else. ${ }^{47}$ Those who bear the burden are mostly family members of the person suffering from the disorder. There is evidence to support that over 80 per cent of persons with intellectual disability remain in the care of the their family. 48

In some societies persons with intellectual disabilities are referred to as 'lees than human,' 'a burden upon society,' 'a menace to society,' 'sick,' 'mentally ill,' 'objects of pity,' 'eternal children,' and 'holy innocents.' 49 These names and perceptions have aggravated the discrimination against persons with intellectual disabilities. Both ancient and some modern cultures consider that intellectual disability is caused by demons or is a punishment from God.50 Even in Biblical times, there are records to show that disabilities are thought to happen because someone sinned. For example in John chapter 9 verse 2, the following conversation took place between Jesus and his disciples:

His disciples asked him, "Rabbi, who sinned, this man or his parents, that he was born blind?

"Neither this man nor his parents sinned," said Jesus, "but this happened so that the works of God might be displayed on him. ${ }^{51}$

The ancient Greeks and Romans considered that intellectual disability was a burden on society and treated persons with this disorder atrociously. ${ }^{2}$ In a study, some respondents volunteered that that they were very anxious, felt afraid and had a strange feeling whenever they had contact with persons with intellectual disability. ${ }^{53}$

\subsection{Nigeria and Persons with Intellectual Disability}

In Nigeria, the way society views disability is largely influenced by culture and religion. Culture here refers to the way of life of a people, on the other hand religion refers to a way of worship of a Supreme Being or a deity. While cultures are localised, religions tend to have more spread. ${ }^{54}$ For example, while Yoruba marriage rites only applies to the Yoruba's in south west Nigeria, saying salat five times a day is a religious rite among Muslims both in the north and south of Nigeria55. Persons who show signs of mental illness in the country are sometimes neglected even by family. There are cases of persons with intellectual disability killed as part of rituals or practices that flow from traditional

47 Julinda Beqiraj, Lawrence McNamara and Victoria Wicks, Access to Justice for Persons with Disabilities: From International Principles to Practice (International Bar Association 2017) 20.

48 Ray Jacques, 'Family Issues' (2018) available at <www.intellectualdisability.info/family/articles/familyissues> accessed 14 September 2018.

49 Tammy Reynolds, CE Zupanick and Mark Dombeck, 'Historical and Contemporary Perspectives on Intellectual Disabilities' (2018) available at < www.mentalhelp.net/articles/historical-and-contemporaryperspectives-on-intellectual-disabilities/> accessed 14 September 2018.

50 Ibid.

51 John 9:2-3 New International Version.

52 Tammy Reynolds, CE Zupanick and Mark Dombeck, op cit (note 47).

53 Thomas Ebenezer and T Giftson, (2018) 'Attitude of the General Public Towards Person with Intellectual Disability with Special Reference to Manachanallur Block' Tiruchirappalli District' IOSR Journal of Humanities and Social Science at 24.

54 Augustine Edobor Arimoro, 'When Love is a Crime: Is the Criminalisation of Same Sex Relations in Nigeria a Protection of Nigerian Culture?’ (2018) 39(3) Liverpool Law Review 221-238.

55 Ibid. 
religious belief systems. ${ }^{56}$ Women with this challenge are also victims of rape with many homeless and often seen on the streets in towns and cities. ${ }^{57}$ Parents of disabled children sometimes have mixed attitudes regarding their children. ${ }^{88}$ Some parents have been found to show positive attitude toward the plight of their disabled children while others maintain a feeling of fear, despair and anger. ${ }^{59}$

The story of Damola Roberts, an athlete who grew up in Nigeria with intellectual disability resonates the plight of persons with that challenge in the country. According to Roberts, as a child he was laughed at, made to eat grass and sand and sadly, even ignored in school by his own sister. 60

There is also an apparent neglect of persons with this challenge from the government in terms of the provision of special schools and infrastructure to assist their inclusion in society. The limited number of special schools in the country means that many school age children with intellectual disability do not go to school or end up in regular schools where they lack the kind of care they should get in addition to being stigmatised by other children who do not full understand the condition of their challenged peers. ${ }^{61}$

Unlike the developed countries of the world where provision in terms of welfare is provided for disabled persons, there is no such welfare plan for the disabled or for their care-givers in Nigeria. The effect is that families who are not well-to-do have difficulties providing adequate care for the disabled members of the family. 62

\subsection{Attitude of the Government of Nigeria to Challenge Faced by Persons with Disability}

Unfortunately, the Federal Government of Nigeria is not very responsive to the plight of disabled persons in the country. Apart from the 1993 Decree on Disability in the country, which incidentally is not even listed in the Laws of the Federation of Nigeria 2004, the government of Nigeria has not taken a real proactive step towards specific legislation for the disabled in the country. The present administration is yet to give assent to a new disability law. Furthermore, there is no evidence of real intent to have a policy of inclusiveness by giving the disabled opportunities to serve as a minister or in high ranking political positions.

The government of Nigeria rarely factor in the plight of persons with disability while making plans. No thought is given to the disabled community in the planning of public buildings, public transport and education. While the government has created ministries to address militants, women and youth, there is no dedicated ministry to cater to the disabled in the Nigerian society. ${ }^{63}$

56 Edwin Etieyibo and Odirin Omiegbe, 'Religion, Culture, and Discrimination against Persons with Disabilities in Nigeria' (2016) African Journal of Disability 5(1) 192.

57 Ibid.

58 Mohammed Awaisu Haruna, op cit (note 3) 105.

59 Ibid.

60 Coca Cola Nigeria, 'A Medal of Hope to Those with Intellectual Disabilities in Nigeria' (2015) available at <www.coca-colaafrica.com/press-centre/a-medal-of-hope-to-those-with-intellectual-disabilities-in-nigeria> accessed 14 September 2018.

61 FN Obaseki and GE Osagie-Obaze 'The Intellectual Disabled (Mentally Impaired) in the Inclusive Type of Education: Problems and Implications' (2009) Edo Journal of Counselling 2 (2) 232.

62 Paul M Ajuwon, 'A Study of Nigerian Families Who Have a Family Member with Down Syndrome' (2012) Journal on Development Disabilities 18(2) 40.

63 Leroy Moore and Julius Shemang 'Government and Disability Activism in Nigeria' Poor Magazine 1 July 2016 available at < http://www.poormagazine.org/node/5549> accessed 14 September 2018. 
4. Framework for the Protection of the Rights of the Person with Intellectual Disability in Nigeria

The protection of the rights of the disabled in general and the person with intellectual disability is anchored on the country's international obligations and the 1999 Constitution of the Federal Republic of Nigeria (as amended). This paper aims to call attention to these instruments which are fundamental to providing support to the person with intellectual disability especially as it concerns the right to access to justice.

\subsection{The United Nation's Convention on the Rights of People with Disabilities (CRPD)}

As noted early in s. I, Nigeria signed and ratified both the CRPD and its Optional Protocol on 30 March 2007 and 24 September 2010 respectively. ${ }^{64}$ As a corollary, Nigeria is under obligation to ensure that the rights of the disabled (including those with intellectual disability) are protected. The purpose of the CRPD defines 'Discrimination on the basis of disability' as follows:

Means any distinction, exclusion or restriction on the basis of disability which has the purpose or effect of impairing or nullifying the recognition, enjoyment or exercise, on an equal basis with others, of all human rights and fundamental freedoms in the political, economic, social, cultural, civil or any other field. It includes all forms of discrimination, including denial of reasonable accommodation. 65

In Article 3, the CRPD under the General Principles of the Convention, lists respect for inherent dignity, individual autonomy; 66 non-discrimination; 67 full and effective participation and inclusion in society; 68 respect for difference and acceptance of persons with disabilities as part of human diversity and humanity; ${ }^{69}$ equality of opportunity; ${ }^{70}$ accessibility; ${ }^{71}$ equality between men and women; ${ }^{72}$ and respect for the evolving capacities of children with disabilities to preserve their identities. ${ }^{73}$ Furthermore, the CRPD provides that states recognise all persons as equal before the law and under the law entitled without discrimination to the equal protection and benefit of the law. ${ }^{74}$ This is the core of this paper which is to advance the promotion of access to justice of persons with intellectual disability. Following from this, it is required of the Nigerian state by virtue of its commitment, to ensure that persons with intellectual disability are not discriminated against whether as main parties to a case, an accused on a witness in any matter before the courts in the Nigeria.

The challenge, however is how can the Nigerian state ensure that the person with intellectual disability gets justice? What mode of trial should be conducted to ensure that such persons adequately state their case before the court? How can the testimonies of

64 Ngozi C Umeh and Ramola Adeola, 'Nigeria' (2013) 1 ADRY 277-290

65 Article 2 CRPD.

66 Article 3 (a) CRPD

67 Article 3(b) CRPD

Article 3 (c) CRPD

Article 3 (d) CRPD

Article 3 (e) CRPD

Article 3 (f) CRPD

Article 3 (g) CRPD

Article 3 (h) CRPD

Article 5 CRPD. 
persons with intellectual disability be taken? What adjustments should be made given the local circumstances in Nigeria? These questions are germane and I will attempt to provide a way forward in the section on recommendations.

\subsection{The African Charter on Human and Peoples' Rights (ACHPR)/Draft Protocol on the Rights of Persons with Disabilities}

This charter also known as the Banjul Charter is an international human rights instrument that is intended to advance and protect human rights and basic freedoms in the African context. ${ }^{75}$ Specifically, the Charter provides for the right to equality before the law and equal protection of the law, ${ }^{76}$ the right of all persons to equality, ${ }^{77}$ as well as the duty to protect human rights. ${ }^{78}$

It is worthy of note that first, the African Commission on Human and Peoples' Rights (ACHPR) has adopted a draft protocol on the rights of persons with disabilities intended to complement the African Charter. Article 9 of the Protocol requires state parties to take all appropriate and effective measures to ensure that persons with disabilities have access to justice on equal basis with others including through the provision of procedural, and age and gender-appropriate accommodations, in order to facilitate their effective roles as participants in legal proceedings. ${ }^{79}$ Secondly, states are obliged to ensure that traditional forms of justice shall not be used to deny persons with disabilities their right to access appropriate and effective justice. ${ }^{80}$ Thirdly, all law enforcement and justice personnel shall be trained at all levels to effectively engage with and ensure the rights of persons with disabilities are recognised and implemented without discrimination; 81 and finally, state parties shall ensure legal assistance including legal aid to persons with disabilities. 82

Following from the above, Nigeria is expected to set up structures within the administration of justice system to assist persons with disability enjoy the right to access justice.

\subsection{The 1999 Constitution of the Federal Republic of Nigeria (CFRN) (as amended)}

Unfortunately, when the Constitution was being drafted, the plight of the disabled was not particularly taken into cognisance. Nevertheless, section 42(2) of the 1999 CFRN indirectly addresses disability by prohibiting discrimination based on the circumstances of the birth of a person. In the same vein, sections 14, 16(1) and 17 of the CFRN guarantee the rights to equality and fundamental rights to all Nigerians. 83

75 African Commission on Human and Peoples' Rights, “African Charter on Human and Peoples' Rights' available at < http://www.achpr.org/instruments/achpr/> accessed 14 September 2018.

76 Article 3 ACHPR.

77 Article 19 ACHPR.

78 Article 25 ACHPR.

79 Article 9 (1) Draft Protocol to the African Charter on Human and People's Rights on the Rights of Persons with Disabilities in Africa.

80 Article 9(2) Draft Protocol to the African Charter on Human and People's Rights on the Rights of Persons with Disabilities in Africa.

81 Article 9 (3) Draft Protocol to the African Charter on Human and People's Rights on the Rights of Persons with Disabilities in Africa.

82 Article 9 (4)Draft Protocol to the African Charter on Human and People's Rights on the Rights of Persons with Disabilities in Africa.

83 Ngozi C Umeh and Ramola Adeola, op cit (note 60) 281. 
Even though, with the exception of the 1993 Disability Decree, no other Act of the National Assembly currently addresses the disability question in Nigeria, it is submitted that the Nigerian government can build on the Draft Protocol on the Rights of Persons with Disabilities to formulate a framework to accommodate the disabled person (and especially the person with intellectual disability) in the administration of justice system in the country. In the next section of the paper, I examine the procedure in place in other jurisdiction to provide some insight on what the government of Nigeria needs to do to comply with the Draft Protocol on the Rights of Persons with Disabilities. In the next section, I discuss the right legal capacity for the disabled person.

\section{The Right of Legal Capacity}

Having discussed the framework upon which persons with intellectual disabilities can exercise their right to access to justice, it is imperative that the issue of legal capacity is given consideration in this paper. The right of persons with disabilities to make choices and to also exercise their legal capacity on an equal basis with others is a right all states including Nigeria must protect. The concept of legal capacity for the person with disability, deals with the ability to choose where and with whom they want to live, to vote at elections, to consent to medical treatment, to sign a lease, to have access to public facilities and other leisure activities. ${ }^{84}$ While this right has gained the attention of the human rights community, its realisation has been slow even in the developed countries of Europe. ${ }^{85}$ However, I note the stride in place and current reforms geared at ensuring that the person with intellectual disability is not deprived of the right to legal capacity especially when it has to do with access to justice. It is submitted that Nigeria should also follow suit by taking the necessary steps to ensure disability rights in the country.

Legal capacity has been defined to be:

A person's power or possibility to act within the framework of the legal system. In other words, it makes a human being a subject of law. It is a legal construct, assigned to most people of the majority age enabling then to have rights and obligations, to make binding decisions and have them respected. As such, it facilitates personal freedom. It enables us to take up a job, get married and inherit property among other things. It also protects the individual against (some) unwanted interventions. 86

If the right of the person with intellectual disability to legal capacity is to be realised, then questions about traditional guardianship laws need to be asked. If a person, even though, one with intellectual disability challenge, is denied the right to legal capacity, it makes it harder for the person to live as an independent human being. ${ }^{87}$ Legal capacity is vital for the disabled person because it is important that such a person is not discriminated against and made to feel less human than others. In the case of the person with an intellectual disability, being under guardianship should not limit the person from rights that define their personality,, 8 for example the right to vote or choose where

84 Council of Europe, Who Gets to Decide? Right to Legal Capacity for Persons with Intellectual and Psychosocial Disabilities (Council of Europe Commissioner for Human Rights 2012) 5.

85 Ibid 9.

86 Ibid at 10.

87 Global Disability Rights, 'Understanding Legal Capacity' (2016) available at $<$ www.globaldisabilityrightsnow.org/tools/understanding-legal-capacity> accessed 15 September 2018.

88 Global Disability Rights, 'Legal Capacity and Persons with Disabilities' (2016) available at

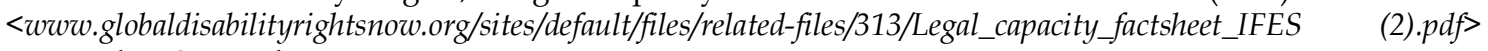
accessed 15 September 2018. 
to spend their leisure. ${ }^{89}$ It remains to be noted however, that for persons with intellectual disabilities, may have limited autonomy at certain periods but when the person retains autonomy, it is important that the person be allowed to exercise choice. The English case of RPv Nottingham City Council90 is instructive here. In that case, RP a 21-year-old woman with a challenge of mild intellectual disability gave birth to baby prematurely. The baby developed substantial health challenges. The health authority, while the baby was in intensive care, initiated formal proceedings to place the baby in care and to eventually place the baby in a foster home. At the period of the decision, the mother was assessed to lack the capacity to instruct a solicitor. Following which a traditional guardian or a guardian ad litem (guardian solicitor) was appointed to represent RP at the proceedings.

The care proceedings resulted in the baby being placed in care. RP and her family petitioned the European Court of Human Rights after several appeals to domestic UK courts. She relied on Articles 6, 8, 13 and 14 of the European Convention on Human Rights (ECHR) arguing that those provisions had been breached. The European Court found rather curiously and also relying on the CRPD as well that the appointment of a guardian in the first place was in order but accepted that RK had litigation capacity to approach it. It has been argued that the decision by the court in $\mathrm{RP}^{\prime} \mathrm{s}$ case is defective and that the petitioner could, from a CRPD perspective, been given the appropriate support to take her place as an active participant in the legal proceedings. ${ }^{91}$

Having considered the need to accord person's with disability the right to access justice above, I examine further, the support the state must provide to assist persons with disabilities, in this case, the person with intellectual disability to exercise legal capacity.

\section{Support for the Persons with Intellectual Disabilities to Exercise Legal Capacity}

In the light of Article 12(3) of the CRPD and following from the RP's case discussed above, it is pertinent that support is provided to persons with disability to have access to justice. Support is necessary given the historical disadvantage that persons with intellectual disabilities face. ${ }^{92}$ The person with intellectual disability would need support in decision-making, expressing his or her will, or having other persons help to communicate their personal identity to the parties in a judicial arrangement. Assistance may be in the form of aids and/or interpreters as well as for special friends. In order to aid the person with intellectual disability to reach a decision, either or more of the following strategies may be employed:

a. The family members or friends of the person with disability may be called upon to assist in decision-making;

b. Use of assisted or adaptive communication aids;

c. Incorporating advocacy support to individual's to protect their rights to legal capacity.

89 See Articles 12 and 29 CRPD.

90 [2008] EWCA Civ 462.

91 Penelope Weller, 'Legal Capacity and Access to Justice: The Right to Participation in the CRPD' (2016) Laws 5(13) 13.

92 Michael Bach, The Right to Legal capacity under the UN Convention on the Rights of Persons with Disabilities: Key Concepts and Directions from Law Reform (Institute for Research and Development on Inclusion and Society 2009) 12. 
Where a person who has an intellectual disability is participating a court trial, the following method may be adopted to ensure that the person's right is protected. First, it is vital that there are trained staff or volunteers ${ }^{93}$ who can meet with the person prior to court to explain what to expect in a way the person can understand. Secondly, the trained friend should be at court with the person and wait until the case is called. Thirdly, the friend should liaise with the court staff to arrange for adjustments the person may need in the court and fourthly, the friend should assist the person to understand the outcome and the implications following the decision of the court. Furthermore, support should be available at pre-trial proceedings, meetings with solicitors, mediation etc.

Where the person is called upon to visit a police station, it is important that a friend is appointed to provide emotional support while talking with the police and in understanding the options available. Trained friends should know, and alert the police about the need to have breaks at intervals. Where the person is alleged to have committed a crime, a friend should be appointed to assist the person understand their rights and help the person to understand legal advice given.

It is fundamental that staff of the judicial system are trained to cater to the needs of persons with disability. In the light of the above, it has been argued that while the criminal justice system is built upon finding justice for persons who are the victims of crime and maintaining order in society and having protections built into the system to ensure fairness, it 'is not a system that was developed to with a full appreciation of the needs and characteristics of all persons in mind.' 94 It follows that the justice system must be tuned up to accommodate the needs of special persons i.e. those with disabilities.

Professional in the judicial system may be trained by learning disability practitioners to accommodate the needs of persons with intellectual disabilities. Staff may need to learn how to make reasonable adjustments to aid persons with intellectual disabilities. For example, in communicating effectively with persons with intellectual disability, it is important to note the following: 95

a. Giving the person extra time to listen and understand what is being said;

b. Asking the person what would help to easily understand things;

c. Putting emphases on words or phrases that they should focus on;

d. Providing the person with a summary of what is about to be said before the detail is discussed;

e. The use of short sentences, with pauses and allowing the person to process the information;

f. Employing the use of visual tools to aid their understanding;

g. Flagging up anything the person say which the you interviewer does not understand; and

h. Asking the person to explain what has been said to check whether they have fully understood.

Some countries have enabled a process to train judicial personnel on dealing with persons with disabilities. For example, Canada in July 2016 launched a mandatory mental health training programme for all LAO employees which is also available to

93 I shall hereafter refer to the trained staff or volunteer as a friend.

94 Tammy Smith, Edward A Polloway, James R Patton and Julia F Beyer, 'Individuals with Intellectual and Developmental Disabilities in the Criminal Justice system and Implications for Transition Planning' (2008) Education and Training in Developmental Disabilities 43(4) 424.

95 NHS England, 'Learning Disability' available at <www.england.nhs.uk/commissioning/wpcontent/uploads/sites/12/2015/10/ohc-paper-05.pdfs accessed 15 September 2018. 
private legal practitioners. ${ }^{96}$ In New Zealand, government provides funding for a collaboration between community institutions to aid access to justice of persons with disabilities. ${ }^{97}$

\section{Challenges in Legal Proceedings Involving Persons with Intellectual Disabilities}

There are several challenges in the quest to ensure that persons with intellectual disabilities get access to justice. Many countries are yet to provide adequate laws to protect disabled persons several years after the CRPD was adopted. The case of Nigeria is worrisome. Apart from the Nigerians with Disability Decree 1993, the Federal Government of Nigeria has not offered any sustainable framework for the protection of disability rights.

Despite the adoption of the CRPD, there still exists discriminatory laws against the intellectual disabled persons including the lack of capacity to conclude contracts or the avenue to participate in the political process. Even though this is not directly linked to the justice system, the general legal discrimination against persons with disabilities has far reaching effect and implications for access to justice. ${ }^{98}$ An example of how persons with intellectual disabilities are discriminated against in the African context, is the Zambian Mental Disorders Act 1951 which identifies persons with disabilities as 'idiots,' 'lunatics,' or persons 'apparently mentally disordered or defective.' Also in Zambia, the Electoral Act No 13 disqualifies persons with psychosocial disabilities from registering as voters (Article 7 (1) (d)). ${ }^{99}$

The lack of awareness, or the deliberate denial of making persons with intellectual disabilities understand their rights is discriminatory as well as a barrier to their realisation of access to justice. In the same vein, the lack of trained personnel, sponsored by the state, to assist the courts in matters involving persons with intellectual disabilities is a barrier to achieving justice. Considering that a significant number of persons with intellectual disabilities go through the criminal justice system as accused, victims or witnesses, it is essential that staff ${ }^{100}$ involved are adequately trained to meet the needs of persons with such disabilities. ${ }^{101}$

A significant barrier to achieving access to justice for persons with intellectual disabilities in Nigeria is the cost of litigation. Relative to the economic situation in Nigeria, 102 it is challenging for persons with disabilities to afford legal fees and the cost of litigation itself. For example, under the current Nigerian Federal High Court Rules, ${ }^{103}$ in order to make a claim of $\$ 10$ million, a fee of over $\$ 50,000$ must be paid the suit is filed. In the next section of the paper, I discuss the way forward for the protection of the rights of the person with intellectual disability to have access to justice in the Nigerian context.

96 Julinda Beqiraj, Lawrence McNamara and Victoria Wicks, Op.Cit (note 46) 21.

97 Ibid.

98 Ibid 22

99 Special Rapporteur on the Rights of Persons with Disabilities Report on Zambia, 2016.

100 Including the police, prosecutors, defence counsel, social workers and health professionals.

101 Julinda Beqiraj, Lawrence McNamara and Victoria Wicks, op cit (note 46) 29.

102 Nigeria has now overtaken India as the world's poverty capital. As at the end of May 2018 about 87 million Nigerians compared with India's 73 million, live in extreme poverty. See Vanguard, 'Nigeria Overtakes India as World's Poverty Capital' The Vanguard 25 June 2018 available at <www.vanguardngr.com/2018/06/nigeria-overtakes-india-as-worlds-poverty-capital-report>> $>16$ September 2018.

103 Order 53 (1) and Appendix 2 of the Federal High Court (Civil Procedure Rules) 2000. 
8. Right to Access to Justice for the Person with Intellectual disability in Nigeria: The Way Forward

In the light of the discussion above, the right approach for the authorities in Nigeria to protect the person with intellectual disability as far is the right to access to justice is concerned, is to take a proactive approach towards establishing a sustainable framework in this regard. The vexed question is, what must the government of Nigeria do? I will attempt to address this in this section. In this vein, the barriers to the realisation of this basic right must be removed including legal, economic, socio-cultural and physical.104

A first step to ensure the rights of the person with intellectual disability to access justice in Nigeria is to make the non-discriminatory provision of the 1999 Constitution of the Federal Republic of Nigeria (as amended) inclusive. Section 42 of the Constitution dealing with the right to freedom from discrimination reads:

A citizen of Nigeria of a particular community, ethnic group, place of origin, sex, religion or political opinion shall not, by reason only that he is such a person:

(a) be subjected either expressly by, or in the practical application of, any law in force in Nigeria or any executive or administrative action of the government, to disabilities or restrictions to which citizens of Nigeria or other communities, ethnic groups, places of origin, sex, religious or political opinions are not made subject; or

(b) be accorded either expressly by or in the practical application of, any law in force in Nigeria or any such executive or administrative action, any privilege or advantage that is not accorded to citizens of Nigeria of other communities, ethnic groups, places of origin, sex, religious or political opinions.

Notwithstanding Nigeria's adoption and ratification of the CRPD and the right to nondiscrimination as expressed in the law above, the situation in the country does not clearly reflect inclusive equality of all persons. The freedom from discrimination offered by the 1999 Constitution is at best merely an idea of formal equality while other countries are pursuing substantive equality. 105 While formal equality means the legal treatment of persons in the same manner notwithstanding their situation in life, substantively equality envisages the circumstances of people and informs the law to ensure equality of outcome. ${ }^{106}$

Sadly, as Umeh notes, despite the strides taken towards constitutional reforms in Nigeria, state actors have failed to consider the peculiarities of persons challenged by disabilities in the legal, socio-economic and political processes. ${ }^{107}$ It is proposed that the Constitution of the country be amended to define in clear terms the rights of persons with disabilities (including those with intellectual disabilities) and to, as a matter of necessity, make such the rights substantive as noted above. All laws that are discriminatory especially those that deny persons with disability their rights to legal capacity must be expunged from the law books.

104 Julinda Beqiraj, Lawrence McNamara and Victoria Wicks, op cit (note 46) 45.

105 Ngozi Chuma Umeh, 'Reading 'Disability' into the Non-Discrimination Clause of the Nigerian Constitution' (2016) 4 African Disability Rights Yearbook 54.

106 O Dupper, 'Affirmative Action and Substantive Equality: The South African Experience' (2002) South African Mercantile Law Journal 275-277.

107 Ngozi Chuma Umeh, Op.Cit (note 102) 53. 
Secondly, the Federal Government of Nigeria must consider passing the Disability Bill into law. ${ }^{108}$ Many Nigerian disability rights have continued to agitate for a law to protect the general interests of persons living with disabilities in the country. The delay in response to this on the part of the Federal Government of Nigeria is disturbing. It is proposed that the Government hasten the process to enable the bill to see the light of day.

Thirdly, it is proposed that selected staff of the judiciary, the police and interested members of the bar should be trained on the handling of cases of persons with intellectual disabilities. A formal training programme led by experts should be established to cater to this need. It is important that persons with intellectual disabilities receive the support that they need. To give support, staff need to understand what kind of support they can, or are required to give.

Fourthly, the rights of the disabled person should be promoted to create awareness. Using the special schools in the country as a platform for this will be helpful in the short to long-term. There should be provision of easy to read materials including visual aids to help persons with intellectual disabilities to know their rights.

Fifthly, it is proposed that the government provides a special fund for legal aid for persons with intellectual disabilities. This is because of their peculiar case as many of them are not able to find employment. It is needful that they are not denied justice on account of legal costs.

A sixth proposal is that the government establishes the office of a disability ombudsman that will champion disability rights in the country. In addition, it is good practice to make available a 24-hour help line for persons with intellectual disabilities. This can be a point of first contact for them in case of emergencies for example, when a person with intellectual disability is arrested for a crime.

Again, it would be helpful to establish a framework that takes into account legal protection, legal awareness, legal aid, adjudication and for civil society oversight of the access of persons with intellectual disabilities to justice. The framework should take into account the proposals advised above. The aim should be to ensure that persons with disabilities enjoy the right to inclusion and are treated not only as humans but also as special.

\section{Conclusion}

In this paper, the focus has been on right to access to justice for persons with intellectual disabilities. As a result of their limited access to their rights, persons with intellectual disabilities are often in a disadvantaged position. There is the need to advance their rights to ensure that they do not suffer from social exclusion. While Nigeria has adopted and ratified the CRPD, the authorities have not taken any steps to ensure that rights of persons with disabilities are properly protected. The need for persons with disabilities to enjoy their basic rights on an equality footing as others is emphasised in the paper. In the case of persons with intellectual disabilities, the peculiar challenges they face including stigmatisation, social deprivation, barriers to access to justice and the lackadaisical approach of the government to their plight have been noted in the paper.

108 Silver Nwokoro, 'Group Urges Buhari to Sign Disability Bill into Law' The Guardian 30 March 2018 available at <https://guardian.ng/news/group-urges-buhari-to-sign-disability-bill-into-law-2/> accessed 16 September 2018. 
The discussion also touched on the current framework for advancing disability rights and the right to access to justice in particular under international and domestic laws. The assessment in this paper is that while the international documents provide the foundation upon which these rights can be built upon domestically, the current framework in Nigeria, if at all there is, is defective. In this light, it is proposed that a holistic framework be put in place to advance the rights of persons with intellectual disabilities to gain access to justice.

\section{References}

Adegoke, Y., \& CNN. (2017, June 26). Nigeria to surpass the US as world's 3rd most populous country. Retrieved from https://edition.cnn.com/2017/06/25/africa/africapopulation-growth-un/index.html

Adeyemo, I. (2018, April 12). Nigeria's Population now 198 million - NPC. Premium Times. Retrieved from http://www.premiumtimesng.com/news/top-news/264781nigerias-population-now-198-million-npc.html

African Commission on Human and Peoples' Rights. (2018). African Charter on Human and Peoples' Rights/Legal Instruments/ACHPR. Retrieved from http://www.achpr.org/instruments/achpr

Ajuwon, P. M. (2012). A Study of Nigerian Families Who Have a Family Member with Down Syndrome. Journal on Development Disabilities, 18(2), 40.

American Association of Intellectual and Development Disabilities. (2018). Definition of Intellectual Disability. Retrieved from $\underline{\text { ttp:///aaidd.org/intellectual-disability/definition }}$

Arimoro, A.E., Are They Not Nigerians? The Obligation of the Nigerian State to End Discriminatory Practices against Persons with Disabilities (2019). International Journal of Discrimination and the Law 89-109.

Arimoro, A.E., When Love is a Crime: Is the Criminalisation of Same Sex Relations in Nigeria a Protection of Nigerian Culture? (2018) 39(3) Liverpool Law Review 221-238.

The Arc. (2011). Causes and Prevention of Intellectual Disabilities. Retrieved from http://www. thearc.org/document.doc?id=3667

Bach, M., \& Institute for Research on Inclusion and Society. (2013). The Right to Legal Capacity under the UN Convention on the Rights of Persons with Disabilities: Key Concepts and Directions from Law Reform. Toronto: Institute for Research on Inclusion and Society.

Beqiraj, J., McNamara, L., \& Wicks, V. (n.d.). Access to Justice for Persons with Disabilities: From International Principles to Practice. International Bar Association.

Coca Cola Nigeria. (2015). A Medal of Hope to Those with Intellectual Disabilities in Nigeria. Retrieved from $h t t p: / / w w w . c o c a-c o l a a f r i c a . c o m / p r e s s-c e n t r e / a-m e d a l-o f-h o p e-$ to-those-with-intellectual-disabilities-in-nigeria

Council of Europe. (2012). Who Gets to Decide?: Right to Legal Capacity for Persons with Intellectual and Psychosocial Disabilities. Strasbourg: Council of Europe Pub.

Degener, T. (2004). Definition of Disability. Retrieved from www.pedz.unimannheim.de/daten/edz-ath/gdem/04/disabdef.pdf 
Disabled World. (2008, January 1). Disability: Definition, Types and Models. Retrieved from $h t t p: / / w w w . d i s a b l e d-w o r l d . c o m / d i s a b i l i t y / t y p e s /$

Dupper, O. (2002). Affirmative Action and Substantive Equality: The South African Experience. South African Mercantile Law Journal, 275-277.

Ebenezer, T., \& Giftson, T. (2018). Attitude of the General Public Towards Person with Intellectual Disability with Special Reference to Manachanallur Block Tiruchirappalli District'. IOSR Journal of Humanities and Social Science, 24. Retrieved from http://www.iosrjournals.org/iosr-jhss/papers/Conf.17004/Volume-4/6.\%202327.pdf

Etieyibo, E., \& Omiegbe, O. (2016). Religion, Culture, and Discrimination against Persons with Disabilities in Nigeria. African Journal of Disability, 5(1). doi:10.4102/ajod.v5i1.192

Global Disability Rights. (2016). Understanding Legal Capacity, Global Disability Rights Now! Retrieved from http://www.globaldisabilityrightsnow.org/tools/understandinglegal-capacity

Global Disability Rights. (2016). Legal Capacity and Persons with Disabilities'. Retrieved from www.globaldisabilityrightsnow.org/sites/default/files/related-files/313/Legal_ capacity_factsheet_IFES (2).pdf

Haruna, M. A. (2017). The Problems of Living with Disability in Nigeria. Journal of Law, Policy and Globalisation, 65, 103.

Intellectual Disability Rights Service. (2009). Introduction to Intellectual Disability. Retrieved from http://www.idrs.org.au/pdf/IDRS_\%20Introduction_intellectual\% 20disability_17Feb09.pdf

Jacques, R. (2018). Family Issues. Retrieved from http://www.intellectualdisability.info/ family/articles/family-issues

Lazcano-Ponce, E., Rangel-Eudave, G., \& Katz, G. (2008). Intellectual disability and its effects on society. Salud Pública de México, 50, s119-s120. doi:10.1590/s003636342008000800001

Leonardi, M., Bickenbach, J., Ustun, T. B., Kostanjsek, N., \& Chatterji, S. (2006). The Definition of Disability: What is in a Name? The Lancet, 368(9543), 1219-1221. doi:10.1016/s0140-6736(06)69498-1

Maulik, P. K., Mascarenhas, M. N., Mathers, C. D., Dua, T., \& Saxena, S. (2011). Corrigendum to "Prevalence of intellectual disability: A meta-analysis of population-based studies" [Res. Dev. Disabil. 32 (2) (2011) 419-436]. Research in Developmental Disabilities, 32(2), 420.

Moore, L., \& Shemang, J. (2016, July 1). Government \& Disability Activism In Nigeria | Poor Magazine. Retrieved from http://www.poormagazine.org/node/5549

NHS England. (2015). Learning Disability. Retrieved from www.england.nhs.uk/ commissioning/wp-content/uploads/sites/12/2015/10/ohc-paper-05.pdf

Nwokoro, S. (2018, March 30). Group Urges Buhari to Sign Disability Bill into Law. Guardian. Retrieved from <https://guardian.ng/news/group-urges-buhari-to-signdisability-bill-into-law-2/> 
Obaseki, F., \& Osagie-Obazee, G. (2010). The Intellectual Disabled (Mentally Impaired) in the Inclusive Type of Education: Problems and Implications. Edo Journal of Counselling, 2(2). doi:10.4314/ ejc.v2i2.60863

Open Society Institute. (2005). Rights of People with Intellectual Disabilities: Access to Education and Employment Romania. Retrieved from www.opensociety foundations.org/sites/default/files/romaniareport_20050902.pdf

Parmenter, T. R. (2011). What is Intellectual Disability? How is it Assessed and Classified? International Journal of Disability, Development and Education, 58(3), 303319. doi:10.1080/1034912x.2011.598675

Raub, A., Latz, I., Sprague, A., Stein, M. A., \& Heymann, J. (2016). Constitutional Rights of Persons with Disabilities: An Analysis of 193 National Constitutions. Harvard Human Rights Journal, 29, 203.

Renolds, T., Zupanick, C. E., \& Dombeck, M. (2018). Historical And Contemporary Perspectives on Intellectual Disabilities. Retrieved from http://www.mentalhelp.net/articles/historical-and-contemporary-perspectives-onintellectual-disabilities/

Sheerin, F. (2009, September 11). We Must Change Approach to Intellectual Disability. Irish Examiner. Retrieved from www.irishexaminer.com/viewpoints/yourview/we-mustchange-approach-to-intellectual-disability-100622.html

Shree, A., \& Shukla, P. C. (2011). Intellectual Disability: Definition, Classification, Causes and Characteristics. International Journal of Disability, Development and Education, 58(3), 303.

Smith, T., Polloway, E., \& Beyer, J. F. (2008). Individuals with Intellectual and Developmental Disabilities in the Criminal Justice system and Implications for Transition Planning. Education and Training in Developmental Disabilities , 43(4), 424.

Umeh, N. C. (2016). Disability' into the Non-Discrimination Clause of the Nigerian Constitution. African Disability Rights Yearbook, 54.

Umeh, N. C., \& Adeola, R. (2013). Nigeria. ADRY, 277-290.

The United Nations. (2018). Convention on the Rights of Persons with Disabilities (CRPD), United Nations Enable. Retrieved from http://www.un.org/development/ desa/disabilities/convention-on-the-rights-of-persons-with-disabilities.html

Vanguard. (2018, June 25). Nigeria Overtakes India as World's Poverty Capital. Vanguard. Retrieved from http://www.vanguardngr.com/2018/06/nigeria-overtakesindia-as-worlds-poverty-capital-report/

Weller, P. (2016). Legal Capacity and Access to Justice: The Right to Participation in the CRPD. Laws, 5(1), 13. doi:10.3390/laws5010013

World Health Organisation. (2018). Disabilities. Retrieved from http://www.who.int/topics/disabilities/en/

World Health Organization. (2011). World Report on Disability: 2011. Geneva: Author.

\section{Conflict of Interest Statement:}

The author(s) declares that the research was conducted in the absence of any commercial or financial relationships that could be construed as a potential conflict of interest.

Copyright (C) 2019 HALREV. All rights reserved. 